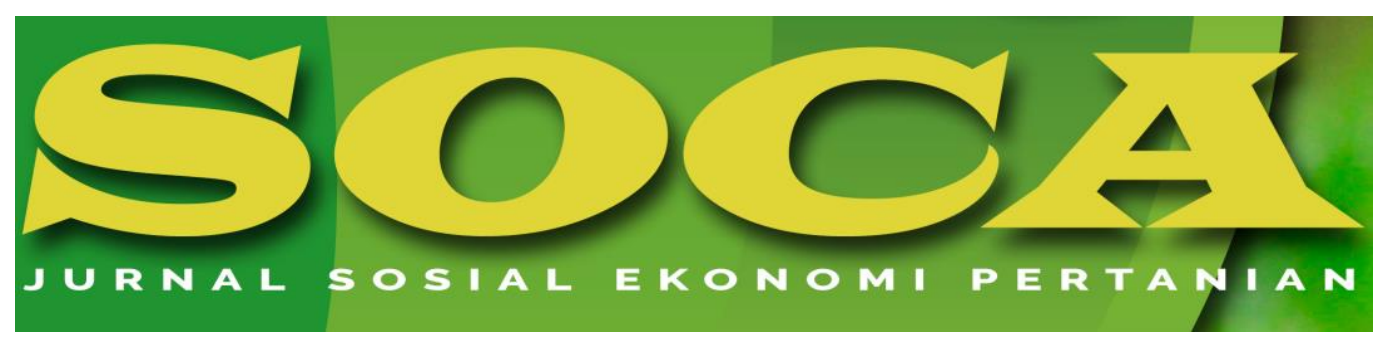

https://ojs.unud.ac.id/index.php/soca

\title{
Marketing Communication on Food Processed (MSME) In Pontianak City
}

\author{
Sapitri, Dewi Kurniati and Shenny Oktoriana. \\ Agribusiness Department, Faculty of Agriculture, Tanjungpura University, Pontianak \\ E-mail:hellopitti.1802@gmail.com,dewiku108@gmail.com, \\ shenny.oktoriana@faperta.untan.ac.id \\ Handphone: 08984747580, 08115747711, 082157747234
}

Submitted: 12 December 2019; Revised: 9 February 2020; Accepted: 19 February 2020

\section{Keywords:}

Micro; Small; Medium

Enterprises

\begin{abstract}
Abstrak
The selection of the marketing communication domain plays a major role in promoting products and services. The most common problem in Micro, Small, and Medium Enterprises (MSME) is its funding system. This study aimed to know the integrated communication marketing used in food processing MSME in Pontianak City. This study was involving 100 participants chosen based on the purposive sampling technique. The analysis method used was descriptive and qualitative analysis. Through a descriptive analysis, the variable studied was described. While, the qualitative analysis applied in assessing the data sources, data reduction, and deducting conclusions or verifications. The result showed that integrated communication marketing that consisted of media advertising, sales promotion, and direct marketing are highly contributed to the food processed sales performance in Pontianak City.
\end{abstract}

How to Cite (APA 6th Style):

Sapitri, Kurniati, D., \& Oktoriana, S. (2020). Marketing Communication on Food Processed ( MSME ) In Pontianak City. SOCA: Jurnal Sosial Ekonomi Pertanian, 14(2), 217-223.

https://doi.org/https://doi.org/10.24843/SOCA.2020.v14.i02.p03

\section{INTRODUCTION}

The original form of Micro, Small, and Medium Enterprises (MSME) is home industries, farming groups, craftsman groups, or cultural communities (Purnomo, 2014). MSME designed to produce a resilient society in the economic aspect. MSME 
plays a significant role in national economic growth. MSME is a component that also contributed to a high amount of funds for national economic growth.

MSME products usually only promoted in the small-scale market. MSME also rarely concentrating on the marketing communication factor because they only focusing on production and selling activities. A proper promotion would support product sales performances. The most common problem in conducting marketing communication in an MSME was the funding system. Rapidly developing information technology is a chance to improve the marketing communication used by MSME in promoting their products and services.

Planned marketing communication is a vital medium in promoting goods and services in economic activity. MSME usually uses some type of marketing communication such as advertising, direct marketing, sales promotion, personal selling, and public relation. A well-planned marketing communication technique was required in promoting MSME products and services. Communication theory was (Harold Lasswell, 1948) the best way to describe a process of communication is by answering questions: (who did say that, what did they say, what kind of media they used, to whom the information want to be shared, and what kind of effect desired by the communicator).

Integrated marketing communication (IMC) is a development and implementation of programs in the form of sustainable persuasive communication done to the consumers or consumer candidates (Shimp, 2010). Marketing communication consists of 4 main techniques: 1) media advertising; 2) sales promotion; 3) personal selling; 4) direct marketing, and 5) public relations.

This study aimed to know the integrated marketing communication on processed food MSME in Pontianak City.

\section{RESEARCH METHODS}

This study was conducted in Pontianak City, West Borneo which involving 100 owners of food processed MSME who chosen by a purposive sampling technique (Sugiyono, 2018). There were four types of food processed MSME participated in this study: (1) cakes, (2) chips, (3) dodol, etc with a total of 1.090 outlets spread all across Pontianak City. The type of data used in this study were primary and secondary data. The data analysis was describing the Lasswell Communication Model applied and a communication marketing technique used in food processed MSME in Pontianak City.

\section{RESULT AND DISCUSSION}

\section{Participant's Characteristic}

The study found that women tend to be more creative than men in finding ideas related to the type of food processed promoted on their business. This could be happened due to women's cultural habit of preparing food in Indonesia. The biological structure of women makes them having a higher intellectual and higher level of creativity than men (Aziz \& Mangestuti, 2006).

The majority of the participant was in 26-35 years of age during the study. This result could also indicate that people in 26-35 years of age are more productive in running a business (Rizqi, etc., 2016).

The level of education on the participant also need to be identified because could show their level of knowledge and skill. A higher level of knowledge also showed a higher level of working skills. Education created people's personalities and 
competencies (Suma'mur, 2009). The majority of the participant in the study was graduated from senior high school (45\%). There was no correlation found between the level of education with the working productivity which indicated that good productivity did not affect by the level of education.

The duration of business experience is a group of events experiencing during running businesses that would affect the level of knowledge and practice in managing their businesses. The longer business experience would contribute to better business skills and a broader network (Asmie P., 2008).

\section{Marketing Communication in Food Processed MSME in Pontianak City \\ 1. Advertising}

The advertising method applied by most MSMEs in Pontianak City was using a banner. Other methods that also used were social media (Instagram, Facebook) and brochures. Banner informed the specific information about the product produced by the MSME including their variant, flavor, composition/ingredient, and price offered. Some MSMEs who used banner as their advertising media stated that banner is could easily be made and did not need much cost to be used in advertising their product. While other MSME who did not use banner stated that banner was not effective in promoting their product.

Some MSMEs also still use the brochure as their advertising media in promoting their business. Brochures are still considered effective because of their low cost and could efficiently promote their business.

Advertising through social media such as Instagram could reach a broader range of marketing areas than conventional media (brochure and banner). The use of social media as the advertising media targeting the use of certain social media types. Some MSME in Pontianak City was using Instagram's influencer or some Instagram account with a high number of followers. Based on the interview, we know that social media is very effective in promoting their product. One of the weaknesses was the high cost used in promoting their business in social media account. Advertising conducted through social media accounts usually more concentrated on giving product information or suggestion to apply the products.

\section{Sales Promotion}

Sales promotion offered a higher value in buying or selling a product. Sales promotion is popular technique use in improving sales performance. This technique also widely used by MSME in Pontianak City. A small-scale competition between MSMEs in Pontianak City was providing a higher chance for each MSME to do effective and creative promotion techniques in advertising their product. Sales promotion is a technique that could be contributed to creative and effective food processed MSME promotion. The interview conducted in this study was shown that most MSMEs using product discounts to improve their sales performances. They stated that a product discount was able to stimulate the consumer to buy a higher amount of product. Another sales promotion technique used was using a lottery and give away. These techniques were easily arranged and very low-priced to be used in increasing sales performances. The lottery was effectively increasing the sales performance because of the present provide by the MSME if the consumer won the lottery is quite attractive. While giveaway strategy was also able to stimulate the consumer to follow each rule prepared by the MSME. 


\section{Personal Selling}

Personal selling is direct selling between the seller and consumer by introducing a product and created a complete understanding of the product offered by the seller. The personal selling was managed by the MSME in Pontianak City in the form of direct selling in their stall. The most MSME di Pontianak City was having a stall to sell their product. To attract consumers, each MSME usually produced unique and different products, for example, different product flavors. The personal selling affected consumer choices to purchase a product because they quickly could get direct information from the seller (Ellisshanty et al., 2017).

\section{Direct Marketing}

Direct marketing is a marketing system that made the seller could be conveyed direct communication with their consumer to create direct marketing communication with their consumer as well. Participants of this study dominantly using this type of technique. A high level of mobilization and responsibilities in Pontianak City make the most of the consumer could not participate in a face-to-face transaction. To deal with this issue, most of MSME using online media such as electronic shopping or e-commerce. The type of E-commerce used is grab or go-jek (Indonesia's online transportation services). This type of marketing communication is a novel marketing technique developed using rapidly developing information technology. The most participant agreed that they could gain higher profit through e-commerce direct selling (Prabowo et al., 2014).

The mostly used marketing communication strategy used was the fourmarketing technique as explained. The direct sales are the most dominant and assumed as the most effective technique used by the MSME.

\section{Laswell Communication Model in Food Processed MSME in Pontianak City}

The first component in advertising was the business owner. The owner was the communicator or the sender of the message that promoting their product through direct and indirect media. The example of direct media was banner and brochure, while the example of indirect media was a social-media account. Banner and brochure are relatively easy to produce and have a low-producing price. A welldesigned banner or brochure also could attract audiences (Susanto et al., 2018).

One of the indirect advertisement media used by the MSME in Pontianak City was the social-media account. They usually use an account own by a celebrity or account with a high number of followers to broadcast information about their products. The product information that was promoted by the communicator would be shifted to the owner of the account. The account owner would be posted the product information and persuade their follower to buy the product. Product promotion through a banner or brochures were usually including some product information such as product's mark, product type, and halal label. A banner usually uses more pictures and color in comparison with the brochure that mostly delivering product information in written form. Advertising a product using a social-media usually would including the same information as the banner and the brochure but tends to be involving more video, picture, and written content. The endorsement could enhance marketing communication in the social media account (Retnowati, et al., 2020). Advertising is a component of marketing communication that could stimulate audiences in understanding messages in the advertisement. Each company always tried to create a creative advertisement to attract the consumer. Employing a celebrity endorser also could affect the level of brand awareness (Laurencia, 2016). 
The selling promotion is involving the owner and/or the staff. The owner is the one who initiated the selling promotion, while the staff is the one who done a transaction with the consumer. Originally the owner is playing the communicator role, but during the application of the selling promotion, the role of the staff could be shifted to the staff. A selling promotion could be done through direct and indirect media. Direct media could be in the form of product discounts or lottery which could be given during a direct transaction with the consumer (usually using a minimal amount of transaction as one of the terms and conditions). Indirect media could be done in the form of a giveaway. The message content on the promotion using lottery was the nominal or type of present given and the present form was a written coupon that would be exchanged with the gift given by the MSME. The message content on the product discount was the amount of discount given, while the message form was the total discount given to the consumer. Selling promotion through product discount positively affect the consumer's buying behavior (Belisa, 2018). Product promotion also could be done through a giveaway. Some rules must be followed by the consumer in a giveaway technique. The most common rules use were through following certain social-media account, liking posts, commenting posts or tagging some friends in certain posts. Marketing communication activity in the Lasswell Communication Model through personal selling was could be observed through the communicator component (owner and staff). Staff was playing a more dominant role because they were doing a more direct transaction to the consumers. The owner also could be contributed in the direct transaction with the consumer because there was no staff employed in the MSME. A direct media was applied because the consumer was buying the product in the MSME stall. The content of the message delivered on personal selling was the interaction between the seller and the consumer personal, the form of personal selling was the voice and touch given during the transaction. The implementation of personal selling is a proper marketing communication strategy in achieving the sales performance's goal and attracting the consumer (Dellamita et al., 2014).

Marketing communication through direct selling was also done by utilizing gojek and grab, an online transportation system in Indonesia. All product information was informed to the company of go-jek and grab by the MSME owner. In this situation, the communicator function that was done by the owner would be shifted to the company of go-jek and grab. A high mobilization and high responsibilities owned by the customer was a major reason in using electronic shopping. Go-jek and grab application is the direct media, transaction done when the customer ordered the food with the application and driver as the media. The product information such as the menu, product price, distance traveled by the driver, a cost that must be paid was included on the online application in the written and figures. Attractive product descriptions and well-designed products also determining the successful level of product marketing through e-commerce (Setiawan, et al., 2018).

Lasswell Communication Model uses also involving a communicant (audience) that could be classified based on age and gender. Based on the age, the audiences for the MSME was ranged between the 16-26 years old. Teen and young adults usually prefer food processed than other people with the elder age. While based on gender, the most audience was female. This also could be happened due to women more favored food processed than men. Another component in this model is advertising, sale promotion, personal selling, and direct selling. While the last component is buying behavior. Women usually contributed a major role in this 
component because they usually have a higher capability in choosing the type of food consumed in the family (Mugaonkar, et al., 2011).

\section{CONCLUSION}

Based on the study result and discussion, we conclude that: The integrated marketing communication done by food processed MSME in Pontianak City was done through some techniques: advertising, selling promotion, personal selling, and direct selling. The most effective and widely marketing communication technique use was direct selling employing electronic media. Integrated marketing communication consists of advertising, selling promotion, personal selling, and direct selling which cited based on Lasswell Communication Model that consisted of five components: (a) The first component is the communicator which is represented by the owner and its staff. (b) The second component is the message which is represented by the message content and the message form sent by the communicator. (c) The third component is the media which is represented by promotion media used by the MSME (direct media and indirect media). (d) The fourth component is the audience which is represented by the consumer that could be classified based on its age and staff. (e) The last component is the effect which did not observe in this study because only represented by the buying performances.

\section{RECOMMENDATION}

The use of electronic media as a marketing communication strategy was effective in improving the sales performance on food processed MSME in Pontianak City. We suggested the MSME use electronic media as the marketing communication strategy in a broader range, for example by joining some shopping websites that provide a wider marketing network (UKMMarket.co.id, Usahadesa.com, Cipika Store, Kriya.co.id, etc).

\section{REFERENCES}

Asmie, P. (2008). Faktor-Faktor yang Mempengaruhi Tingkat Pendapatan Pedagang Pasar Tradisional di Kota Yogyakarta. Jurnal NeO-Bis, Vol. 2(2), 197-210.

Aziz, R., \& Mangestuti, R. (2006). Tiga Jenis Kecerdasan dan Agresivitas Mahasiswa. Jurnal Psikolog (21).

Belisa, N. (2018). Pengaruh Sales Promotion Voucher Diskon Melalui Media Sosial Instagram @Brosisdeal Terhadap Keputusan Pembelian Konsumen di Marchant Lokal Pekanbaru. Jurnal FISIP, Vol. 5 (1).

Dellamita, M. F., Fauzi, A., \& Yulianto, E. (2014). Penerapan Personal Selling Untuk Meningkatkan Penjualan (Studi pada PT Adira Quantum Multifinance Point of Sales Dieng Computer Square Malang). Jurnal Adminitrasi Bisnis, 9 (2).

Ellisshanty, Iga, S., \& Harti. (2017). Pengaruh Harga. Kualitas Produk, dan Promosi Terhadap Keputusan Pembelian di UKM Bakso Kemasan M di Mojokerto. Jurnal Pendidikan Tata Niaga, Vol. 1(1), 49-54.

Lasswell, H. (n.d.). Structure an Function of Communication In Seciet. 2009: Wilbur Schramm. 
Laurencia, S. (2016). Pengaruh Penggunaan Celebrity Endorser Isyana Sarasvati Dalam Iklan "Isyana vs Gengster" Terhadap Brand Awareness Masyarakat Surabaya. Jurnal E-Komunikasi, 4 (1).

Mugaonkar, Ananthan, Samal, \& Debnath. (2011). Studi Tentang Perilaku Konsumen. Pertanian Usulan Penelitian Ekonomi, 24, 133-140.

Prabowo, H., Darman, \& Noegraheni. (2014). Analisis Kepercayaan Dalam C2c ECommerce Terhadap Keputusan Pembelian \& Dampaknya Terhadap Repurchase Pada Kaskus. Binus Bisnes Review, Vol. 5(1), 301-304.

Purnomo, A. (2014). Efektivitas Pembiayaan UMKM akan Musyarakah Pada Nasabah Baitul Maal Wat Tamwil Beringharjo Cabang Malioboro Yogyakarta. Jurnal Pendidikan \& Ekonomi, Vol. 3 (6), 950-959.

Retnowati, N. D., Indrianingsih, Y., \& Honggowibowo, A. S. (2020). Pemanfaatan Endorse dan Hastag Untuk Pemasaran Produk Menggunakan Instagram Pada UMKM di Kecamatan Patuk Kabupaten Gunung Kidul. Jurnal Pengabdian pada Masyarakat, 3.

Rizqi, R., Putri, \& Ardyanto. (2016). Hubungan Gizi Dengan Produktivitas Kerja Tenaga Kerja Bagian Sorter and Packers. Skripsi.

Roni, G. G. (2015). Meningkatkan Penjualan Melalui Konsep Komunikasi Pemasaran Terpadu Di UMKM. Management.

Setiawan, T. F., Suharjo, B., \& Syamsun, M. (2018). Strategi Pemasaran Online Umkm Makanan. Jurnal Manajemen Ikm, Vol. 13(3), 116-126.

Shimp, T. A. (2010). Advertising Promotion and Other Aspects of Interated Marketing Communication. Canada: Nelson Education, Ltd.

Sugiyono. (2018). Metode Penelitian Kuantitatif Kualitatif dan R\&D. Jakarta: CV Alfabeta.

Suma'mur. (2009). Hygiene Perusahaan dan Kesehatan Kerja. Jakarta: Gunung Agung.

Supriyanto. (2006). Pemberdayaan Usaha Mikro Kecil dan Menengah (UMKM) Sebagai Salah Satu Upaya Penanggulangan Kemiskinan. Jurnal Pendidikan Ekonomi, Vol. 3 (1), 1-16.

Susanto, T. T., Kusnadi, E., \& Retno, L. (2018). Penggunaan Spanduk dan Brosur Sebagai Bahan Penunjang Media Publisitas Kegiatan. Jurnal Pengabdian Kepada Masyarakat, Vol. 1(3), 576-584.

Tavris, W. D. (2017). Psikologi. Jakarta: Erlangga. 